\title{
Penilaian Resiko Kesehatan Lingkungan-EHRA (Fasilitas dan Perilaku Warga Perumahan Karanglo Indah) Terhadap Sampah Rumah Tangga
}

\author{
Sunik ${ }^{1}$, Deddy Kristianto ${ }^{2}$, Lila Khamelda ${ }^{3}$ \\ 1,2,3 Jurusan Teknik Sipil, Fakultas Teknik, Universitas Katolik Widya Karya, Jl. Bondowoso 2 Malang \\ e-mail : ssunik@widyakarya.ac.id, 087859032994
}

\begin{abstract}
ABSTRAK
Perumahan Karanglo Indah, Kelurahan Balearjosari, Kecamatan Blimbing, Malang, Jawa Timur adalah salah satu perumahan menengah dengan beberapa masalah terkait dengan layanan sampah yaitu: 1) frekuensi pengambilan oleh petugas dari rumah ke rumah belum terpenuhi, 2) timbunan sampah yang tidak rutin diambil pada TPS menimbulkan bau tidak sedap dan mengganggu, terlebih efek samping pada musim penghujan berupa bau, air sampah, lalat dan belatung semakin meningkat, 3) terjadi gunungan sampah karena timbunan sampah tidak diangkut menuju TPA pusat, 4) setiap rumah tangga sering membuang sendiri sampah ke TPS, 5) belum adanya kesadaran pemilahan sampah rumah. Tujuan penelitian ini adalah mendapatkan pemetaan hasil analisis penilaian resiko (EHRA) dalam bentuk persentase terkait fasilitas (layanan pembuangan-pengumpulan sampah) dan perilaku sanitasi (pemilahan sampah) terhadap sampah warga perumahan. Metode penelitian yang dilakukan adalah sosialisasi, survei dan wawancara kepada warga RW IV (RT 01 - RT 07) dan RW X (RT 04 dan RT 06).Terdapat \pm 26 blok, blok A - blok FF, populasi sekitar $364 \mathrm{KK}$ dan ditetapkan $96 \mathrm{KK}$ sebagai sampel. Analisis data kuisioner menggunakan program bantu Excel dan SPSS. Analisis awal adalah reliabilitas dan validitas kuisioner. Analisis lanjutan berupa persentase hasil análisis EHRA berdasar rekapitulasi kuisioner. Hasil analisis penilaian resiko (EHRA) terkait fasilitas yaitu cara utama pembuangan sampah adalah 51,04\% warga membuang sendiri ke TPS, frukuensi pengangkutan sampah 39,58\% dilakukan sekali dalam seminggu, pengangkutan sampah 50\% menyatakan bahwa kadang sampah diangkut kadang tidak meski $95,83 \%$ warga membayar iuran sampah (1 x dalam sebulan). Untuk perilaku sanitasi tentang sampah berupa pemisahan sampah sebelum dibuang (organik,sampah basah, dapur \& logam, gelas, plastik), 64,58\% menyatakan memilah sampah sebelum dibuang dengan pertimbangan supaya bersih $(72,92 \%)$. Kesimpulan penelitian yaitu fasilitas dan perilaku sanitasi warga tentang sampah masih beresiko terhadap kesehatan, warga masih kurang sadar dan peduli tentang sanitasi sampah dan pemilahannya.
\end{abstract}

Kata kunci: perilaku sanitasi; pemilahan sampah; EHRA

\begin{abstract}
Karanglo Indah Residential, Balearjosari Village, Blimbing Subdistrict, Malang, East Java is one of the middle residential with several problems related to waste services, namely: 1) the frequency of officers taking home-to-home has not been fulfilled, 2) landfills that irregular taken at laystall causes unpleasant odors and disturbances, especially the side effects in the rainy season in the form of odors, garbage water, flies and maggots are increasing, 3) there is a mountain of garbage because the landfill is not transported to the central landfill, 4) each household often throws garbage into laystall by own, 5) there is no awareness of sorting home waste. The research purpose was to obtain a map as analysis results of the risk assessment (EHRA) in the form of percentages related to facilities (garbage collection-collection services) and sanitation behavior (waste sorting) towards residential waste. The research method that used was socialization, surveys and interviews to residents of RW IV (RT 01 - RT 07) and RWX (RT 04 and RT 06). There were +26 blocks, block A - block FF, a population of around 364 bousebolds and 96 bouseholds as a sample. Questionnaire data analysis using Excel and SPSS as assistance programs. The initial analysis is the reliability and validity of the questionnaire. Further analysis in the form of percentage of EHRA analysis results based on questionnaire recapitulation. Results of the risk assessment analysis (EHRA) related to facilities as the main method of waste disposal
\end{abstract}


was $51.04 \%$ of residents throw the disposal by their own to the laystall station, the frequency of transporting waste was $39.58 \%$ done once a week, for garbage transport $50 \%$ stated that sometimes garbage was transported, sometimes it was not, even $95.83 \%$ of residents pay garbage fees (each month). For sanitation behavior about waste in the form of waste separation before being disposal (organic, wet waste, kitchen \& metal, glass, plastic), $64.58 \%$ stated that they sorting the waste before being disposed in consideration of being clean $(72.92 \%)$. The research conclusion for sanitation facilities and behavior of residents about waste were still at risk against to health, people were still less aware and lack of care about waste sanitation and sorting.

Keywords : sanitation behavior; waste sorting; EHRA

\section{PENDAHULUAN}

Salah satu program dari 6 (enam) program pembangunan kesehatan berdasar KepMenKesNo.1202/MENKES/SK/VIII /2003 [4] adalah program lingkungan sehat, perilaku sehat dan pemberdayaan masyarakat. EHRA (Environmental Health Risk. Assessment) [5],[6],[9] adalah kajian yang bertujuan untuk memetakan kondisi fasilitas sanitasi dan perilaku-perilaku yang memiliki risiko pada kesehatan warga. Fasilitas sanitasi yang diteliti umumnya mencakup sumber air (minum, cuci, mandi, kelangkaan air), layanan pembuangan sampah (cara utama, frekuensi dan pengangkutan, pemilahan), jamban, dan saluran pembuangan air limbah. Untuk perilaku yang dipelajari adalah yang terkait dengan hieginitas dan sanitasi, antara lain, cuci tangan pakai sabun, buang air besar, dan pemilahan sampah. EHRA adalah kajian yang dilakukan menggunakan pendekatan kuantitatif dengan menerapkan 2 (dua) teknik pengumpulan data, yakni 1) wawancara (interview) dan 2) pengamatan (observation). Yang menjadi unit analisis dalam EHRA adalah rumah tangga sementara yang menjadi unit respon adalah ibu rumah tangga.

Perumahan Karanglo Indah, Kelurahan Balearjosari, Kecamatan Blimbing adalah perumahan menengah dengan jumlah Kepala Keluarga \pm 364 KK.
Meski termasuk kategori perumahan menengah ke atas, fasilitas sanitasi berupa kebersihan/layanan sampah (satu dari 5 point dalam studi EHRA) menjadi masalah utama di perumahan ini. Beberapa masalah berkaitan dengan kebersihan/layanan sampah adalah 1) frekuensi pengambilan oleh petugas dari rumah ke rumah belum terpenuhi, 2) timbunan sampah yang tidak rutin diambil pada TPS menimbulkan bau tidak sedap dan mengganggu, terlebih efek samping pada musim penghujan berupa bau, air sampah, lalat dan belatung semakin meningkat, 3) terjadi gunungan sampah karena timbunan sampah tidak diangkut menuju TPA pusat, 4) setiap rumah tangga sering membuang sendiri sampah ke TPS, 5) belum adanya kesadaran pemilahan sampah.

Penelitian ini menggunakan kuisioner dan merujuk pada skala Likert untuk klasifikasi secara kuantitatif. Menurut Sekaran [7], "the interval scale not only groups individuals according to certain categories dan taps theorder of these groups; it also measures the magnitude of the differences in the preferences among the individuals", artinya skala interval tidak hanya mengelompokkan individu ke dalam kategori tertentu, namun juga mengukur besarnya perbedaan preferensi antara individu yang satu dengan lainnya. Data yang diperoleh dalam skala ordinal akan diubah menjadi skala interval dengan menggunakan skala Likert [2, 10]. 
Pengukuran responden terhadap fasilitas dan perilaku sanitasi menggunakan indeks sikap untuk mengetahui sikap dan pertimbangan responden. Dengan pengukuran ini akan diperoleh timbangan terhadap fasilitas dan perilaku (sampah) beserta peringkat keutamaannya mulai dari pertimbangan yang selalu dilakukan hingga pertimbangan yang tidak pernah dilakukan. Data kepercayaan dan evaluasi individu diukur berdasarkan skala sikap. Skala ini digunakan untuk mengetahui tanggapantanggapan responden terhadap pertanyaan yang diajukan. Alternatif tanggapan responden adalah 1) sangat setuju-nilai 5, 2)setuju-nilai 4, 3) ragu-ragu-nilai 3, 4) tidak setuju-nilai 2,5) sangat tidak setuju-nilai 1.
Pengelolaan sampah dalam kajian EHRA [3],[8] adalah pengumpulan, pengangkutan, pemrosesan, pendaurulangan, atau pembuangan dari material sampah yang dihasilkan dari kegiatan manusia, dan biasanya dikelola untuk mengurangi dampaknya terhadap kesehatan, lingkungan atau keindahan. Pengelolaan sampah dapat dibagi ke dalam dua aktivitas utama yaitu pengumpulan dan pemrosesan akhir.

Pada dasarnya terjadi proses daur ulang dari kedua aktivitas ini. Dasar hukum adalah UU No. 18/2008 [8] tentang Pengelolaan Sampah. Aktifitas utama terkait pengelolaan sampah ditunjukkan pada Gambar 1 dan Gambar 2.

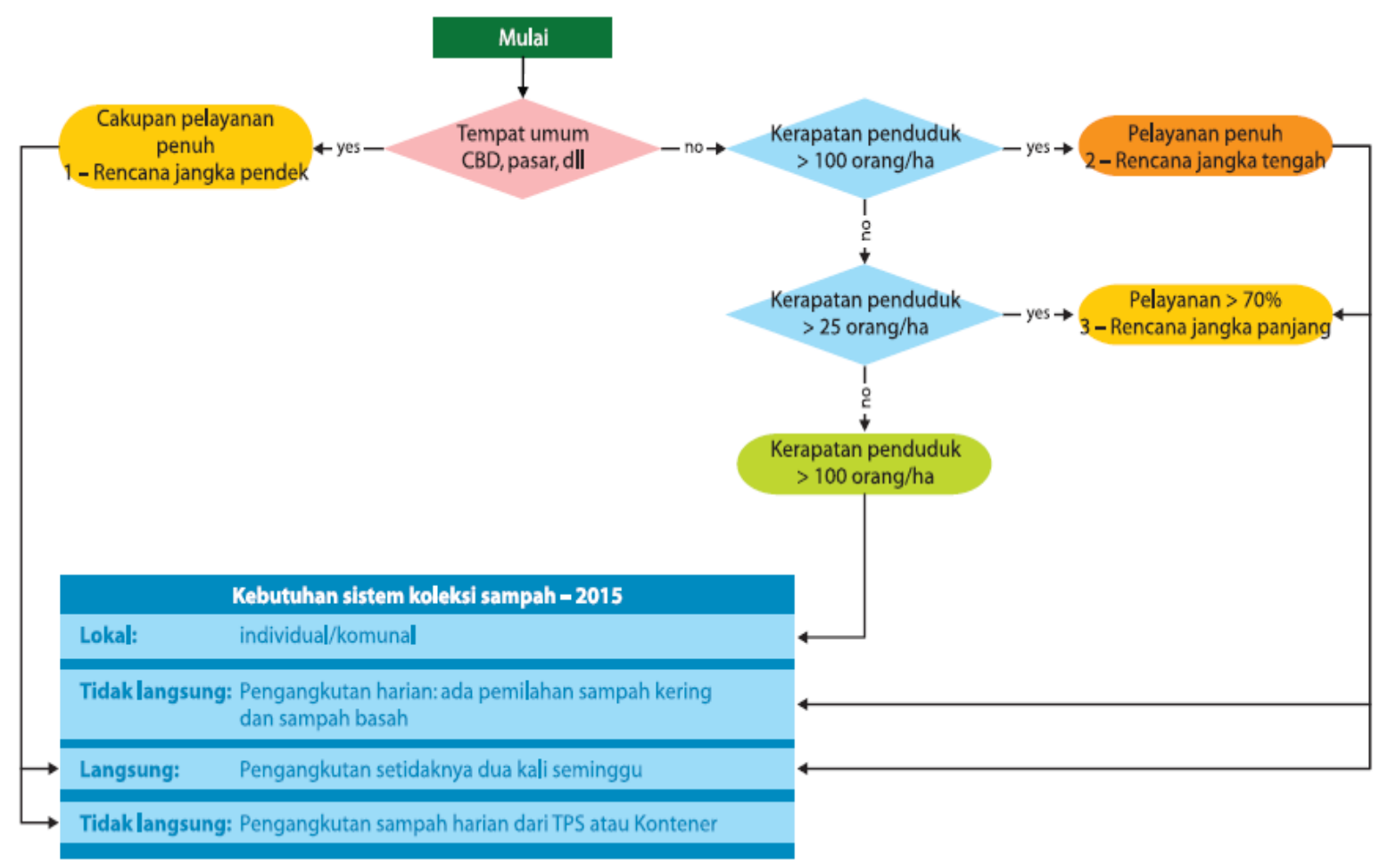

Gambar 1. Pengelolaan sampah, pengumpulan dan adur ulang 


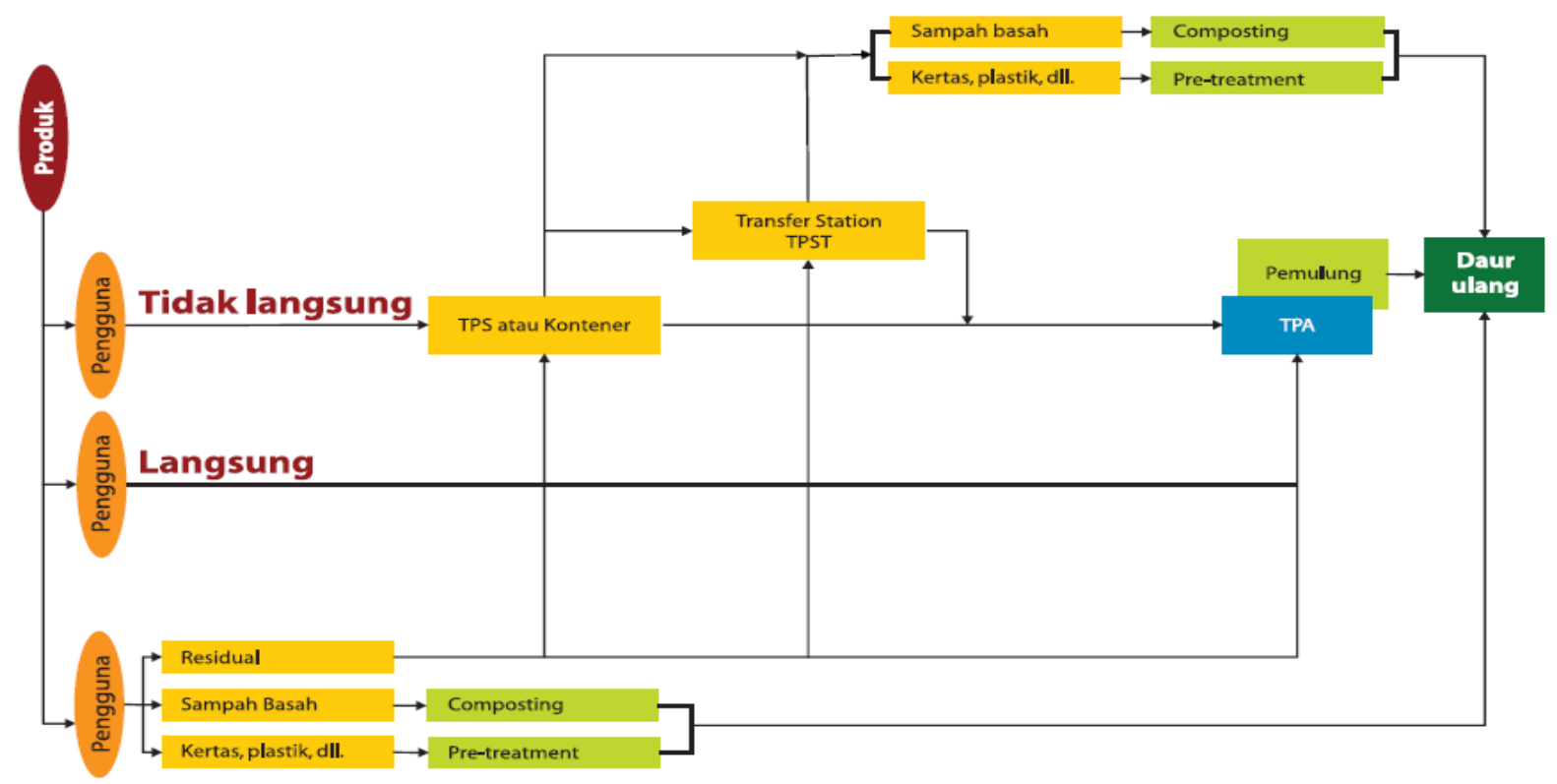

Gambar 2. Pengelolaan sampah, pemilihan awal dan skala prioritas

Berdasar uraian tersebut maka dilakukan penelitian ini untuk mendapatkan pemetaan [1] hasil analisis penilaian resiko (EHRA) dalam bentuk persentase terkait fasilitas (layanan pembuangan-pengumpulan sampah) dan perilaku sanitasi (pemilahan sampah) terhadap sampah warga perumahan.

\section{METODE PENELITIAN}

Penelitian ini dilaksanakan di Perumahan Karanglo Indah, Kelurahan Balearjosari, Kecamatan Blimbing dengan periode waktu 7 bulan, terdiri dari 1 bulan kegiatan persiapan, 4 bulan kegiatan survei dan pengumpulan data, 1 bulan kegiatan pengolahan data, analisis data, presentasi dan sosialisasi, 1 bulan kegiatan penyusunan Laporan Pendahuluan dan Laporan Akhir. Evaluasi dilakukan 2 kali yaitu evaluasi terhadap hasil wawancara, metode pendekatan dan kuisioner untuk melihat pengetahuan dan perilaku responden tentang sampah serta evaluasi terkait umpan balik hasil presentasi dan sosialisasi. Gambar 1 menunjukkan letak perumahan Karanglo Indah.

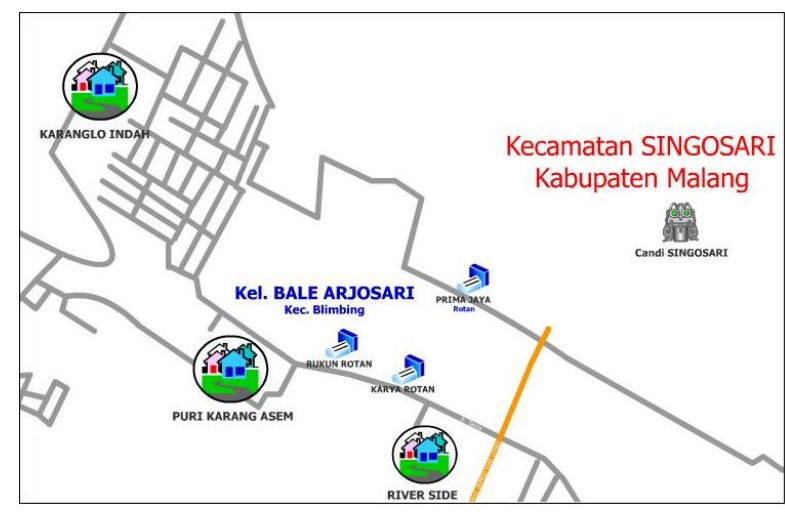

Gambar 1. Perumahan Karanglo Indah

Objek penelitian ini adalah warga perumahan Karanglo Indah, Kelurahan Balearjosari, Kecamatan Blimbing, Malang. Warga yang dimaksud adalah warga RW IV (RT 01 - RT 07) dan RW X (RT 04 dan RT 06, masing-masing RT rata-rata terdiri dari $\pm 30-35 \mathrm{KK}, \pm 26$ blok, blok A - blok FF, populasi sekitar $364 \mathrm{KK}$ ). Di setiap blok, sampel rumah diambil secara acak \pm 
10 - 15 KK. Metode pengambilan data/pengumpulan data primer dilaksanakan melalui kegiatan survei yaitu melakukan wawancara dengan responden (sampel 96 responden) rumah tangga menggunakan kuesioner. Wawancara dan pengamatan dirancang untuk diselesaikan dalam waktu sekitar 30-45 menit.

\section{Tabel 1. Rekapitulasi jumlah KK}

\begin{tabular}{|c|c|c|c|c|c|c|c|c|}
\hline \multirow{2}{*}{ No } & \multirow{2}{*}{ RW } & \multirow{2}{*}{ RT } & \multirow{2}{*}{ Blok } & \multirow{2}{*}{ Ho } & \multicolumn{3}{|c|}{ Jumlah KK } & \multirow{2}{*}{ Jumlah } \\
\hline & & & & & $\mathbf{L}$ & $\mathbf{P}$ & HA & \\
\hline 1 & \multirow{22}{*}{ RW IV } & 01 & $T$ & $01-32$ & 26 & 5 & 3 & 34 \\
\hline \multirow{2}{*}{2} & & \multirow{2}{*}{02} & $Q$ & $01-16$ & 9 & 3 & 2 & 14 \\
\hline & & & $\mathrm{R}$ & $01-36$ & 19 & 11 & 7 & 37 \\
\hline \multirow{3}{*}{3} & & \multirow{3}{*}{03} & $G$ & $01-25$ & 7 & 5 & 0 & 12 \\
\hline & & & $\mathrm{U}$ & $01-27$ & 9 & 0 & 1 & 10 \\
\hline & & & $W$ & $03-23$ & 13 & 3 & 4 & 20 \\
\hline \multirow{4}{*}{4} & & \multirow{4}{*}{04} & $\mathrm{I}$ & 01-14 & 12 & 1 & 1 & 14 \\
\hline & & & J & $02-11$ & 7 & 2 & 1 & 10 \\
\hline & & & $k$ & 01-11 & 7 & 3 & 0 & 10 \\
\hline & & & $L$ & $01-07$ & 4 & 1 & 1 & 6 \\
\hline 5 & & 05 & $S$ & $01-29$ & 19 & 7 & 5 & 31 \\
\hline \multirow{6}{*}{6} & & \multirow{6}{*}{06} & A & $19-45$ & 6 & 6 & 1 & 13 \\
\hline & & & B & $07-34$ & 14 & 1 & 0 & 15 \\
\hline & & & $\mathrm{C}$ & $01-29$ & 5 & 5 & 2 & 12 \\
\hline & & & $\mathrm{D}$ & $01-22$ & 9 & 0 & 0 & 9 \\
\hline & & & $\mathrm{E}$ & $01-10$ & 4 & 0 & 2 & 6 \\
\hline & & & $\mathrm{P}$ & $01-07$ & 3 & 3 & 1 & 7 \\
\hline \multirow{5}{*}{7} & & \multirow{5}{*}{07} & $\mathrm{~F}$ & $02-26$ & 10 & 4 & 0 & 14 \\
\hline & & & $\mathrm{H}$ & 01-12 & 9 & 1 & 0 & 10 \\
\hline & & & $M$ & 02-04 & 3 & 0 & 0 & 3 \\
\hline & & & $\bar{V}$ & $01-11$ & 4 & 1 & 1 & 6 \\
\hline & & & $\mathrm{C}$ & 34 & 0 & 1 & 0 & 1 \\
\hline \multirow{2}{*}{8} & \multirow{5}{*}{ RW X } & \multirow{2}{*}{04} & $N$ & $01-20$ & 15 & 2 & 3 & 20 \\
\hline & & & 0 & $01-14$ & 9 & 2 & 2 & 13 \\
\hline \multirow{4}{*}{9} & & & $\mathrm{DD}$ & $01-21$ & 10 & 3 & 2 & 15 \\
\hline & & 06 & $\mathrm{EE}$ & $01-22$ & 10 & 2 & 3 & 15 \\
\hline & & & $\mathrm{FF}$ & $05-17$ & 5 & 2 & 0 & 7 \\
\hline & & & & & & \multicolumn{2}{|c|}{ KK TOTAL E } & 364 \\
\hline
\end{tabular}

Berikut beberapa gambaran kondisi TPS ditampilkan pada Gambar 3.

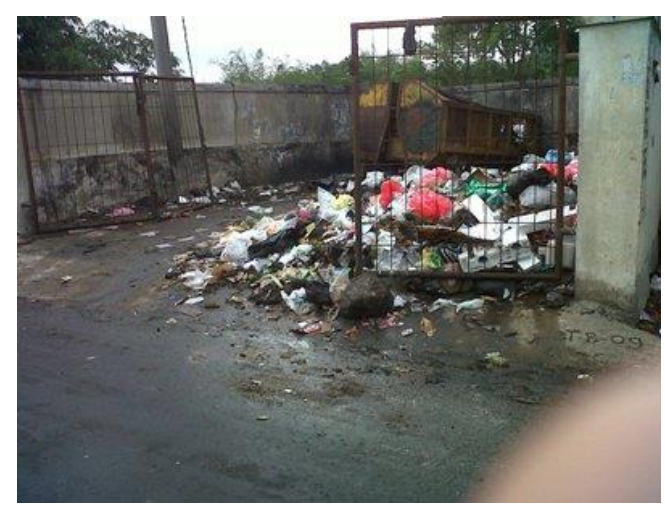

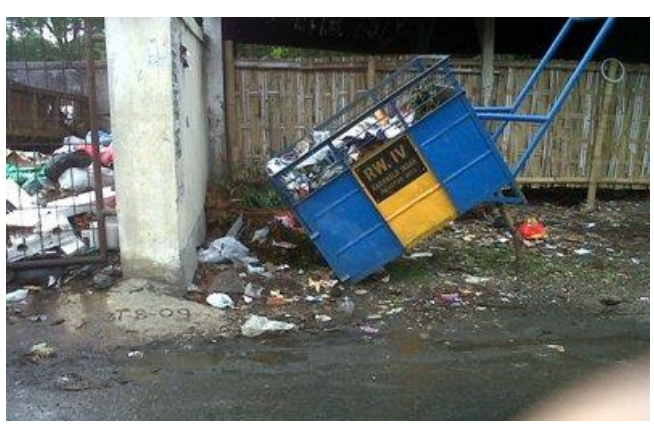
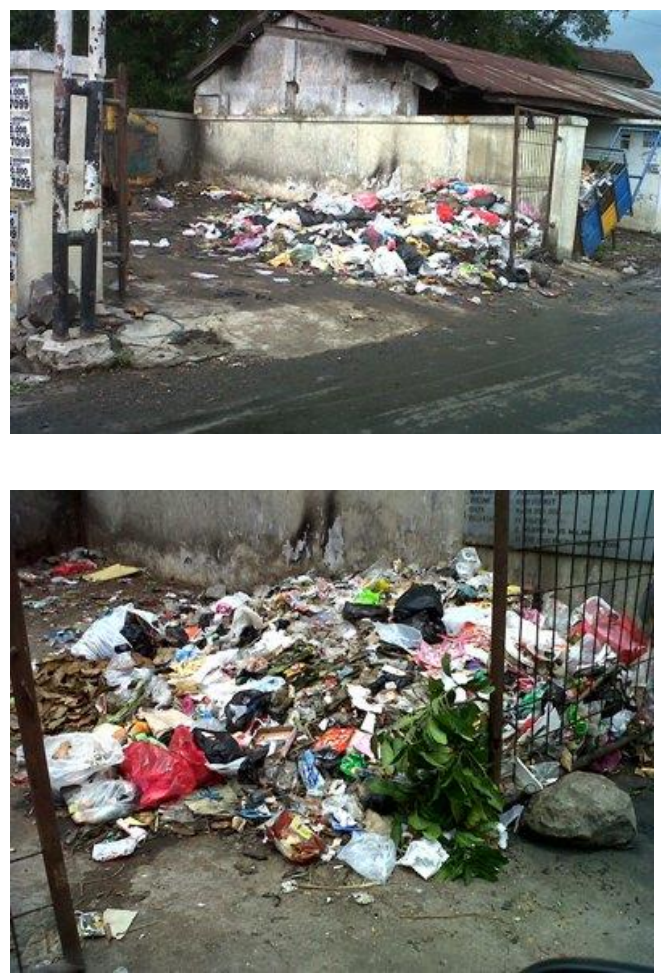

\section{Gambar 3. Kondisi TPS Perumahan Karanglo Indah}

Pengumpulan data berupa isian kuisioner dalam penelitian EHRA dilakukan melalui kolaborasi dengan kader PKK dengan sejumlah pertimbangan, yakni 1) kader-kader memiliki akses yang mudah untuk datang ke rumah-rumah dan diterima oleh RT/ RW dan warga penghuni rumah. Pertimbangan ini terkait erat karakteristik responden yang merupakan ibu berusia antara 27-60 tahun (ibu atau perempuan yang menikah atau cerai atau janda, perempuan atau ibu dipilih sebagai responden dalam EHRA karena mereka 
adalah kelompok warga yang paling memahami kondisi lingkungan di rumahnya) dan pertanyaan di dalam kuesioner banyak mengandung hal-hal yang dalam norma masyarakat dinilai sangat privat, 2) kader umumnya memahami wilayah RT sehingga mempermudah mencari rumah yang dipilih random. Kuisioner diberikan kepada 96 responden berisi 9 (sembilan) pertanyaan dengan butir pertanyaan yang merujuk pada skala likert terkait 1) cara pembuangan sampah utama, 2) frekuensi pengangkutan sampah, 3) ketepatan pengangkutan sampah, 4) Pelayanan pengangkutan sampah, 5) pemilahan sampah, 6) tujuan pemilahan sampah, 7) fokus kebersihan sampah, 8) pengumpulan sampah, 9) pelayanan pengangkutan sampah.

Analisis awal hasil pengumpulan data kuisioner menggunakan validitas dan reliabilitas, analisis lanjutan terkait persentase menggunakan program bantu sederhana yaitu Excel dan SPSS.

\section{HASIL DAN PEMBAHASAN}

EHRA tentang sampah menelusuri 3 (tiga) aspek yang mencakup 1) cara pembuangan sampah utama di rumah tangga, 2) frekuensi \& pendapat tentang ketepatan pengangkutan sampah bagi mereka yang mendapat layanan pengangkutan sampah, dan 3) praktik pemilahan sampah di tingkat rumah tangga.

Hasil penelitian terkait cara pembuangan sampah utama ditampilkan pada Gambar 4.

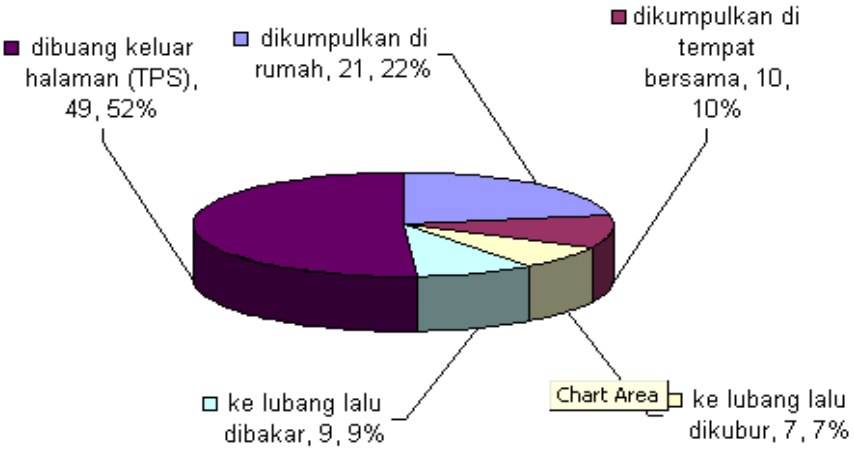

Gambar 4. Cara pembuangan sampah utama

Peringkat pertama cara yang paling umum dilakukan oleh rumah tangga dalam membuang sampah adalah cara ke empat, yakni membuang ke luar halaman dalam hal ini membuang ke tempat pembuangan sementara (TPS), sebanyak $52 \%(51,04 \%)$, sedangkan peringkat kedua adalah cara pertama yakni dikumpulkan di rumah lalu diangkut petugas RT/RW, sebanyak $22 \%$ (21,88\%). Peringkat ke tiga, sampah dikumpulkan bersama lalu diangkut oleh petugas RT/RW, sebanyak 10\% (10,42\%).

Hasil penelitian terkait frekuensi pengangkutan sampah ditampilkan pada Gambar 5.

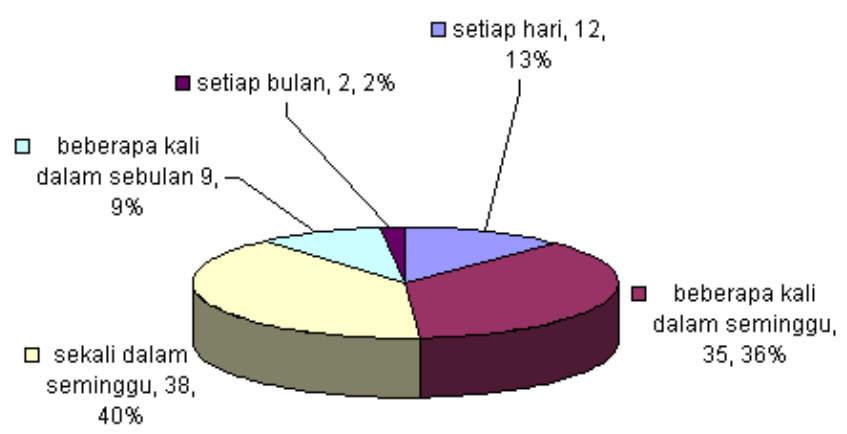

\section{Gambar 5. Frekuensi pengangkutan sampah}

Hasil menunjukkan bahwa sampah warga diangkut setiap hari $=13 \%$ (12 responden), beberapa kali dalam seminggu 36\% (35 responden), sekali dalam seminggu $=40 \%$ (38 responden), beberapa kali dalam 
sebulan $=9 \%$ ( 9 responden $)$, setiap bulan $=$ $2 \%$ (2 responden). Sampah yang tidak diangkut dalam kurun waktu satu minggu atau lebih dari satu minggu akan menimbulkan resiko kesehatan warga perumahan. Hasil penelitian terkait ketepatan pengangkutan sampah ditampilkan pada Gambar 6.

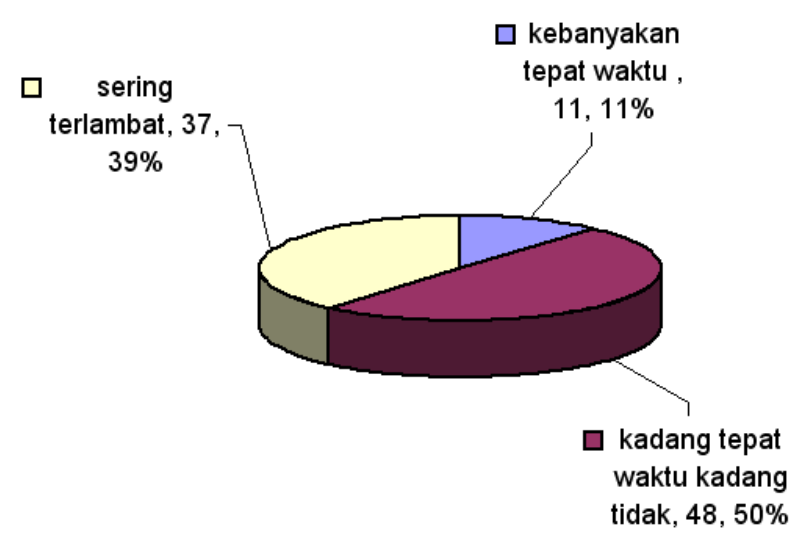

Gambar 6. Ketepatan waktu pengangkutan sampah

Hasil terkait ketepatan waktu pengangkutan menunjukkan $11 \%$ responden (11 responden) berpendapat bahwa pengangkutan sampah kebanyakan tepat waktu, sedangkan $50 \%$ responden (48 responden) berpendapat kadang tepat waktu kadang tidak, 39\% responden (37 responden) berpendapat bahwa pengangkutan sampah sering terlambat. Pelayanan pengangkutan sampah ditampilkan pada Gambar 7.

tidak mendapat

layanan pengangkutantidak membayar, $4,4 \%$

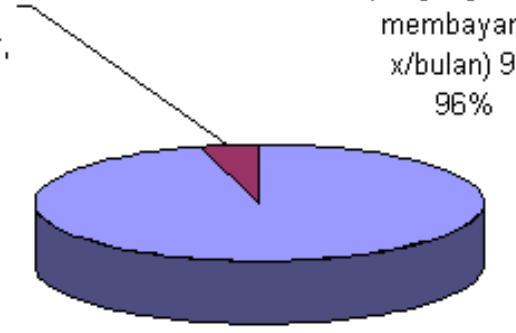

Hasil terkait layanan pengangkutan, 96\% responden (96 responden) menjawab mendapat layanan pengangkutan sampah dan membayar ( $1 \times$ per bulan), sedangkan $4 \%$ responden (4 responden) tidak mendapat layanan pembuangan sampah dan tidak membayar (ini disebabkan karena warga tersebut membuang sampah di halaman rumahnya sendiriditimbun/dibakar di lubang).

Hasil penelitian terkait pemilahan sampah sebelum dibuang ditampilkan pada Gambar 8.

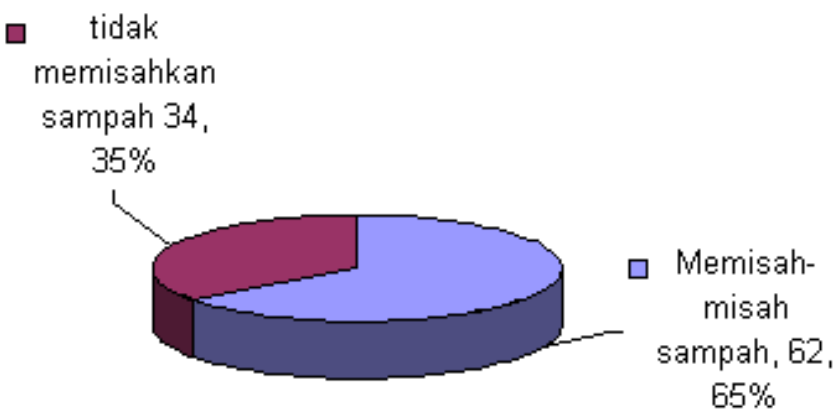

Gambar 8. Pemilahan sampah

Hasil terkait pemilahan sampah menunjukkan $35 \%$ responden (34 responden) menjawab tidak memilah sampah (organik,sampah basah, sampah dapur, logam, gelas dan plastik) sebelum dibuang dengan pertimbangan melakukan hal tersebut lebih cepat, mudah, praktis dan bersih, semua jenis sampah langsung ditempatkan dalam kantong plastik, sedangkan 65\% responden (62 responden) menjawab memilah-milah sampah sebelum dibuang.

Hasil penelitian terkait tujuan pemilahan sampah ditampilkan dalam Gambar 9.
Gambar 7. Pelayanan pengangkutan sampah 


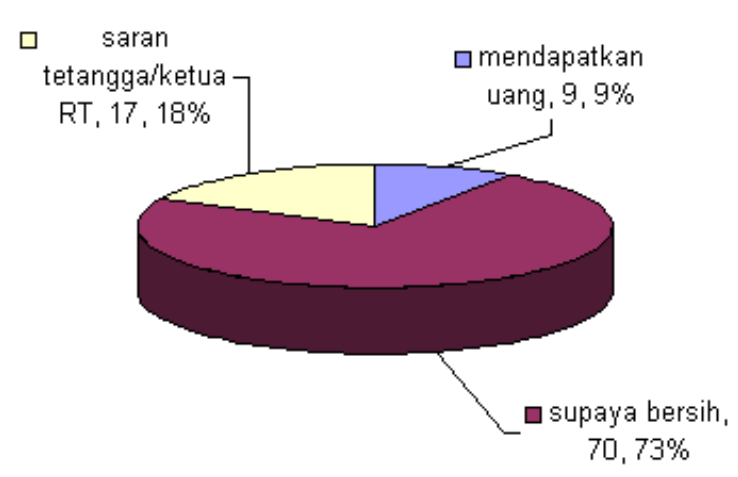

\section{Gambar 9. Tujuan pemilahan sampah}

Hasil terkait pemilahan sampah sebelum dibuang dengan pertimbangan bahwa ada jenis sampah yang dapat dijual kembali/mendapatkan uang (koran, gelas, plastik) $=9,38 \% \quad(9$ responden $)$, memudahkan pemulung dalam mencari/memungut sampah di TPS/supaya bersih $=72,92 \%$ (70 responden), dan mengikuti saran dari tetangga/ketua RT = $17,71 \%$ (17 responden).

Hasil penelitian tentang fokus kebersihan sampah terkait penempatan sampah ditampilkan pada Gambar 10.

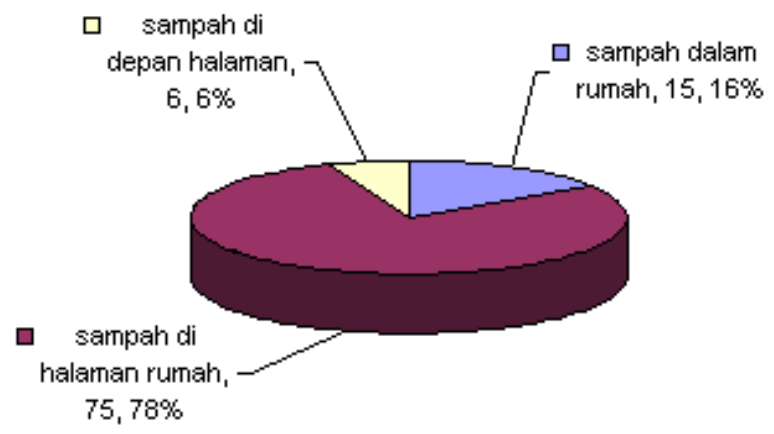

\section{Gambar 10. Fokus kebersihan sampah}

Hasil terkait fokus kebersihan sampah, 16\% responden (15 responden) menempatkan sampah dalam rumah, $6 \%$ responden (6 responden) menempatkan sampah di depan halaman dan $78 \%$ responden (75 responden) menempatkan sampah di halaman rumah. Dapat disimpulkan bahwa responden yang paling sedikit mengalami resiko kehatan adalah responden yang menempatkan sampah di depan halaman/pekarangan rumah.

Hasil penelitian terkait pengumpulan sampah ditampilkan pada Gambar 11.

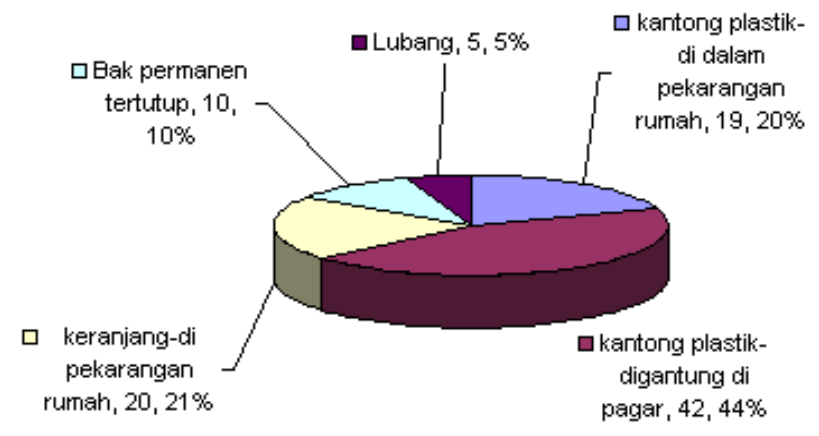

Gambar 11. Pengumpulan sampah

Hasil untuk pengumpulan sampah, 44\% responden (42 responden) mengumpulkan sampah di kantong plastik dan digantung di pagar dengan pertimbangan memudahkan petugas untuk memungut sampah, sampah tidak dikoyak oleh binatang (kucing, tikus), mengurangi bau yang ditimbulkan sampah dan memudahkan untuk membuang ke TPS (bila belum terangkut oleh petugas) karena warga belum tentu ada di rumah (untuk warga pekerja), 20\% responden (19 responden) mengumpulkan sampah di kantong plastik dan ditempatkan di halaman/pekarangan untuk argumen kebersihan, 21\% responden (20 responden) mengumpulkan sampah di keranjang dan ditempatkan di pekarangan rumah dengan pertimbangan memudahkan pengangkutan ke TPS, sedangkan $10 \%$ responden (10 responden) mengumpulkan sampah di bak permanen tertutup dengan pertimbangan sampah dikumpulkan bersama untuk diangkut petugas.

Hasil penelitian terkait pelayanan pengangkutan sampah ditampilkan pada Gambar 12. 


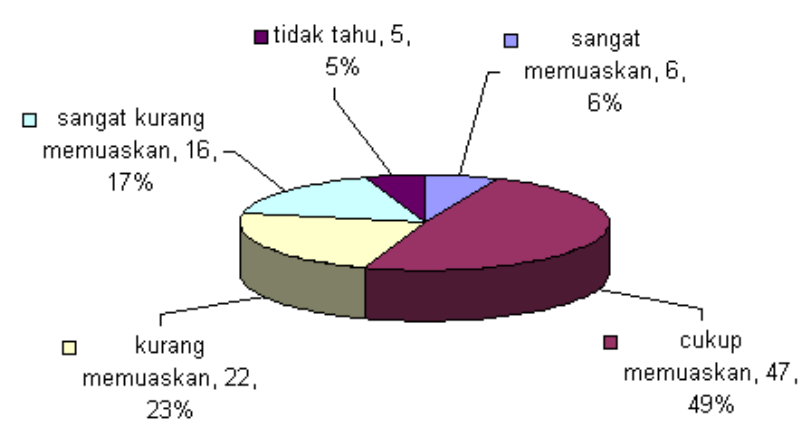

Gambar 12. Pelayanan pengangkutan sampah

Untuk pelayanan pengangkutan sampah, $6 \%$ responden (6 responden) berpendapat bahwa layanan pengangkutan sampah sangat memuaskan (ini disebabkan karena ada kemungkinan pemberian tip/uang lelah ke petugas pengangkutan), 49\% responden (47 responden) berpendapat cukup memuaskan (pengangkutan kadang tepat waktu kadang tidak), 23\% (22 responden) berpendapat kurang memuaskan (pengangkutan sering terlambat,ada kemungkinan karena tidak adanya tip/uang lelah atau blok yang letaknya terlalu jauh dari TPS), 17\% responden (16 responden) berpendapat pengangkutan sangat kurang memuaskan (karena sering adanya keterlambatan pengangkutan, dapat terjadi karena tidak adanya tip/uang lelah dan 5\% responden ( 5 responden) menjawab tidak tahu karena responden ini tidak mendapat pelayanan pengangkutan sampah, tidak membayar dan mereka menimbun sampah di lubang/dikubur/dibakar.

\section{KESIMPULAN}

Hasil analisis (persentase) penilaian resiko (EHRA) pada warga Perumahan Karanglo Indah, Kelurahan Balearjosari, Kecamatan Blimbing, Malang terkait fasilitas berupa cara utama pembuangan sampah adalah 51,04\% warga membuang sendiri ke TPS, sedangkan frukuensi pengangkutan sampah 39,58\% dilakukan sekali dalam seminggu, untuk pengangkutan sampah 50\% menyatakan bahwa kadang sampah diangkut kadang tidak meski 95,83\% warga membayar iuran sampah (1 x dalam sebulan). Untuk perilaku sanitasi tentang sampah berupa pemisahan sampah sebelum dibuang (organik,sampah basah, dapur \& logam, gelas, plastik), 64,58\% menyatakan memilah sampah sebelum dibuang dengan pertimbangan supaya bersih $(72,92 \%)$. Berdasar uraian tersebut disimpulkan bahwa data primer sanitasi sampah tingkat RT telah diperoleh, yaitu bahwa fasilitas dan perilaku sanitasi warga tentang sampah masih beresiko terhadap kesehatan, warga masih kurang sadar dan peduli tentang sanitasi sampah dan pemilahannya.

Untuk penelitian lanjutan dapat dilakukan penelitian dengan keterlibatan kelompok kerja (PokJa) yang lebih optimal dalam bentuk penyuluhan/sosialisasi menggunakan sistem pre-test dan post test sebagai base awal untuk penyusunan program sadar peduli sanitasi sampah dengan monitoring/evaluasi setiap 2 (dua) bulan sekali setelah pelaksanaan program. Penelitian lanjutan lainnya yang dapat dilakukan terkait EHRA adalah fasilitas dan perilaku sumber air minum, saluran air limbah, pemanfaat sampah menggunakan konsep 3R.

\section{DAFTAR PUSTAKA}

[1]

$$
\text { Environmental Health Risk }
$$
Assessment. Guidelines for assessing human health risk from environmental hazard. 2012. ISBN: 978-1-74241-766-0. Commonwealth of Australia. www.health.gov.au 
[2] Rensis,Likert.1932. A Technique for The Measurement of Attitudes. New York University.

[3] Rusdin Rauf, dkk. 2016. Gambaran Pengelolaan Sampah Rumah Tangga di Kabupaten Kudus Tahun 2016. Studi EHRA I. Jurnal Kesehatan, ISSN 1979-7621, Vol. 1, No. 2, 2016

[4] Keputusan Menteri Kesehatan. 2003. Indikator Indonesia Sehat 2010 dan Pedoman Penetapan Indikator Provinsi Sehat-Kabupaten/Kota Sehat. Depatemen Kesehatan R.I. Jakarta.

[5] LAPORAN STUDI EHRA (Environmental Health Risk Assessment). 2013. Program Percepatan Pembangunan Sanitasi Pemukiman. Kabupaten Lampung Barat Provinsi Lampung

[6] LAPORAN STUDI EHRA (Environmental Health Risk Assessment). 2014. Program Percepatan Pembangunan Sanitasi
Pemukiman. Pemerintah Kabupaten Langkat Provinsi Sumatera Utara.

[7] Sekaran, U. 1992. Research Methods for business: A skill-Building Approach (2n ed).Canada:John Wiley \& Sons, Inc

[8] Undang-undang Republik Indonesia Nomor 18 tahun 2008 tentang pengelolaan sampah.

[9] Panduan Praktis Pelaksanaan EHRA (Environmental Health Risk Assessment/Penilaian Risiko Kesehatan karena Lingkungan).2014. Pokja AMPL.

[10] Weksi,B. 2013. Skala Pengukuran dan Jumlah Respon Skala Likert. Jurnal Ilmu Pertanian dan Perikanan, Vol. 2 No. 2, ISSN 2302-6308. http://umbidharma.org/jipp. 